\title{
An Address of the 2008 Global Financial Crises with Unconventional Monetary Policies
}

\author{
Baneng Lucas Naape, Mamokgaetji Marius Masoga \\ Department of Economics, University of Limpopo, South Africa \\ Banengnaape@gmail.com, Mariusmasoga@gmail.com
}

\begin{abstract}
This study aims to assess the impact and spill over effects of the United States (US) Quantitative Easing (QE) to South Africa. Using an event-study analysis on daily data spanning from 25/11/2008 $12 / 12 / 2012$ for selected QE dates, the study finds that US Treasury bills fall by 106 basis points on average during QE1, rise by 9 basis points and 8 basis points during QE2 and QE3, respectively. For South Africa, government bonds fall by 61 basis points on average during QE1, 9 basis points during QE2 and 2 basis points during QE3. This leads to the conclusion that UMPs boost the economy in the short run but hurt the economy in the long run, especially when targeting inflation, and used extensively. Therefore, policymakers should concentrate on the overall financial system to measure the financial risk, and thus consistently strengthen macro prudential orientation.
\end{abstract}

Keywords: Global financial crisis, quantitative easing, event study analysis, unconventional monetary policy, interest rates.

\section{Introduction}

The central banks normally influence aggregate demand and ensure price stability using short term interest rates - the so called conventional monetary policy (Horvath, 2017). However, since the dawn of post-financial crisis era of 2007-2008, countries around the world adopted Unconventional Monetary Policies (UMPs) to protect their economies against disastrous effects of the financial crisis (Yasin et al., 2013). The UMPs as described by Korniyenko and Loukoianova (2015), range from purchases of large scale private and public debt securities up to direct lending to banks. They have been adopted with an intention to inter alia, ensure that monetary policy is accommodative at the zero-lower bound of interest rates, and ensure that financial markets have liquidity. As Bowdler \& Radia, (2012) elaborated, the emergence of financial crisis jeopardised the liquidity and solvency of systematically important financial institutions, such as Lehman brothers in the US and Northern Rock, amongst others. As a result, the functioning of the financial markets became severely impaired (Bowdler \& Radia, 2012).

The Federal Reserve Bank, European Central Bank, Bank of Japan and Bank of England responded to the financial crisis using UMPs and managed to unleash roughly $\$ 9.5$ trillion (Subacchi, 2013). This has appeared as a collective reaction since central banks in advanced economies applied similar expansionary paths when faced with ballooning budget deficit, public debt, credit crunch and recession. The debris of the financial crisis as argued by Yasin et al. (2013) cannot be cleaned by monetary policy as this is not cost effective and interest rate policy is insufficient. Since interest rate policy appeared not enough for averting massive detriment induced by financial crisis, Borio (2011) highlighted that UMPs have been adopted so that countries scramble and reorganize their balance sheets. This was done in order to broadly influence financial conditions and long-term interest rates and give guidance to credit terms and credit spreads. When interest rates approach zero, UMPs are considered. As a result, low interest rates fuel spending, which raises the profits of nonfinancial firms. Furthermore, borrowing becomes less costly, resulting in business expansions, declines in unemployment rates, which further leads to lower loan delinquencies and charge-off rates.

All of these are necessary to mitigate risk and have a healthy economy and sound financial system (Chodorow-Reich, 2014). Two sets of UMPs have been enacted since 2009, both intending to achieve varied goals. The first and second rounds of the United States (US) UMPs began in December 2008 and November 2010 respectively, with the former aimed at increasing the avaliability of credit in private markets and the latter at strengthening the economic recovery and combating a possible Japanese-style deflationary outcome (Liber8 Newsletter, 2011). The European Central Bank (ECB) latter announced its own programme of UMPs in January 2015 (Oosthuizen, 2016). Meanwhile advanced economies implemented safety measures thereof, it is worth noting that expansionary policies like UMPs has some spill over effects for other countries. This study aim to assess how South Africa felt the strains owing to UMP measures applied by advanced economies. 
Bhattarai, Chatterjee and Woong (2015) revealed that QE resulted in an exchange rate appreciation, increased capital inflows, a stock market boom and reductions in long-term bond yields in emerging economies.

Nevertheless, there are limited studies that explicitly examined how South Africa was influenced by unconventional monetary policies. Instead, existing studies generally aimed to assess the consequences of such policies on developing countries Asia and the Pacific region (Punzi and Chantapacdepong, 2017). An event-study analysis is a rarely applied methology, especially on studies similar to this particular study. For instance, Stephanos Nikolaos, \& Panayiotis, (2019) explored the spillover effects on the stock markets of six African countries and Middle Eastern emerging market economies during and after the implementation of unconventional monetary policies by US, using classical, dynamic, and time-varying Granger causality tests. Whilst it is important to acknowledge that UMPs affected most countries in the global economy, the discussion in this paper features unique aspects in terms of methodolgy and presentation of thoughts and/or arguments to broaden literature and therefore contribute additional knowledge and understanding on the topic under scrutiny. The paper is structured as follows; section 2 outlines literature review. Section 3 discusses methodology of the study. The findings of the study and interpretation are presented in section 4. The conclusion and policy recommendations are presented in sections 5.

\section{Literature Review}

Theoretical Literature: The signalling and portfolio-balance channels are the transmission channels suggested in UMP theory (Cecioni et al., 2011). The activation of signalling channel is when central banks communicate with the public, notifying them about intentions regarding future evolution of short-term interest rates. The activation of portfolio-balance channel is via operations of the central bank like outright purchase of securities, liquidity injections and asset swaps also called Quantitative Easing (QE). As a result, the size and composition of balance sheet become modified for both the central banks and private sector (Cecioni et al., 2011). Figure 1 shows the process of Unconventional Monetary Policy (UMP) using a diagram, indicating how UMP works from large scale asset purchases to increases in wealth, lower borrowing costs, capital expansion and depletions in inventory.

\section{Figure 1: The process of Unconventional Monetary Policy (UMP)}

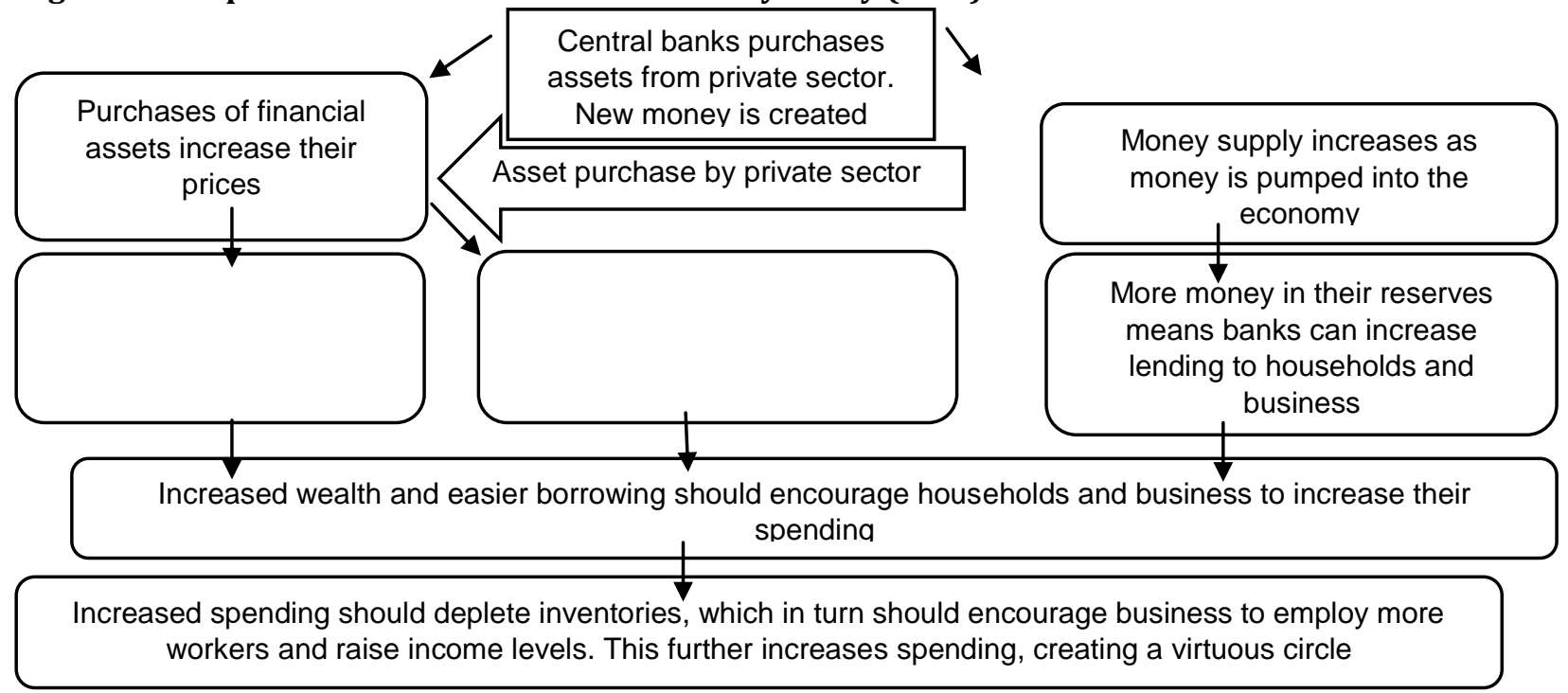

Source: Bank of England Pamphlet (2011)

Central banks are often concerned with the risks of low inflation rates. As such, they usually reduce their lending rates so that borrowing becomes less costly to financial institutions and the public at large. Since interest rates cannot fall below zero, central banks inject new electronic money into the economy through the purchase of assets such as government bonds and high-quality debt from private companies (Liber8 
Newsletter, 2011). The idea is not to print more banknotes but to credit the sellers' bank accounts which results in new electronic money in the wider economy. The sellers will have more money in their bank accounts, while their banks will have a comparable claim against the central bank. Additionally, this study provides a leeway for future research in terms of engaging more on country focused discussions, unlike broad-based assessements on particular group of countries, which may to some extent limit the scope of debates. The sellers, having more money, are then able to increase their spending, thereby boosting growth (Bank of England (Reich, 2014), 2011). UMPs are considered when interest rates are near zero.

Empirical Literature: The aftermaths of global economic and financial crises in 2007/08 have triggered the use and application of unconventional monetary policy measures. As a result, this sparked greater amount of research by academics, scholars and researchers alike. Most interestingly, the key theme that benefited wide scrutiny was appraisal of the effectiveness of unconventional monetary policies (Rossi, 2018). The significant impact of UMPs in developed economies has been through ensuring liquidity within financial markets (Tatiana, 2013). Nonetheless, Borio and Zabai (2016) argued that, there is still an on-going debate about the effectiveness of these UMPs since it is tough to disentangle their impact. In contradiction, the impact has been confirmed to exist since Tatiana (2013) found that UMPs relatively had significant impact within real economy and financial markets in developed countries. According to Francois and Mathieu (2016), the positive effects of large-scale asset purchases remained uncertain on both inflation and the economy. This is despite their effectiveness in supporting financial markets in the period of crisis. Korniyenko and Loukoianova (2015) observed that, from 2008 to 2014, there has been significant expansion in balance sheets of central banks which adopted UMPs. This means that there have been more purchases of large-scale assets.

Bernanke (2009) observes that, economic recovery cannot be sustainable if there is crisis within the financial systems. The idea of central banks to adopt UMPs was not bad because dealing with certain economic shocks require possible effective policies that are available. Reich (2014) found that UMPs boosts growth and causes inequality to reduce. As evidence evolved, empirical results found by Kapetanios et al. (2012) suggest that in the absence of UMPs, real GDP in England would have exacerbated in 2009, and inflation also would have become negative. In the presence of conventional monetary policy, low and stable inflation have been achieved, but the occurrence of asset market bubbles was not averted (Joyce, Miles, Scott, \& Vayanos, 2012). According to Kapetanios et al. (2012), UMPs were effective to assist UK economy to avert the likelihood of deflation and deep recession. The counterfactual analysis has been done by Lenza et al. (2010) who used large BVAR model to provide evidence that UMPs have been successful in restoring the functioning of the financial markets given the noticeable contraction in money spreads. Similarly, it has been stated by Vinals et al. (2013) that the functioning and intermediation of the markets have been restored by UMPs. The consistent under-performance of the economy coupled with inflation in early 2000s led the bank of Japan to resort in massive purchase of assets (Francois 2016).

In the United States, UMPs averted contraction, and the reason why US has experienced rapid recovery from great recession than some of its counterparts is because of UMPs (Bhattarai, Eggertsson and Gafarov, 2015). The research by Cecioni, et al. (2011) found that, macroeconomic effects of UMP in Fed and ECB were significant in averting deflation thread and collapse of output. Unconventional Monetary Policies such as purchasing of public and private assets and currency swaps have been adopted to avert the collapse of the financial system and a devastating depression (Tatiana, 2013). However, from the observation of public opinion, this created and still creates the risk of undesirable side-effects. In comparison with standard monetary instruments, the substantial fiscal and re-distributional effects may incur as a result of unconventional operations (Tatiana, 2013). Bhattarai, et al. (2015) indicated that, QE creates mismatch duration on the balance sheet of the central banks as it issues short-term debt in exchange for long term assets. As a result, "This opens up the possibility of possible future balance sheet losses/gains by the central bank, because the price of its liabilities may fall/rise relative to its assets" (Bhattarai, et al., 2015: 2). Furthermore, it has been highlighted by Bhattarai, et al. (2015) that, quantitative easing or UMPs are problematic since they do not work in theory, but only work in practice.

The Potential Risks Associated with Unconventional Monetary Policies: As coined out by Meier (2009), UMPs impose financial and political risks. As far as the former is concerned, private sector has been at risk previously. Therefore, when central banks purchase assets in the private sector, the credit access might 
ameliorate, and valuations of assets may be boosted. But, this will cause significant loss of capital if the assets acquired lose value over time. As a result of capital losses, the discretionary of central banks would be undermined, and their capacity to maintain inflation would be adversely affected (Weale and Wieladek, 2014). As far as the latter is concerned, the balance sheet of the central banks can survive some financial loss as a result of strong existing capital cushions (Meier, 2009). However, the reputational risk relating to the possible criticism of squandering taxpayer money may occur. In general, as Meier (2009) advocated, unconventional operations have tendency of heightening the proximity between monetary and fiscal policies, potentially threatening the focus of central banks on price stability. In addition, the chief among the risks of UMPs is the risk of inflation and profitability of financial institutions.

UMPs were critically important in breaking the downward trend caused by the 2008 global financial turmoil as apparent from earlier discussions. However, UMPs became a problem rather than a solution when it was used for an extended period (Kenc et al., 2011). The longer the highly accommodative stance remains in place, the more probable its reactions are to develop. Most significantly, UMPs failed to restore economic growth, more especially in Europe and Japan. The prolonged UMPs have resulted in rising commodity and financial market prices, while promoting risk-taking behaviour in investing and punishing savers by subduing bond yields. This explains the slow growth in many countries. Instead of reflating the global economy, UMPs in Europe and Japan is shrinking it. Therefore, the following set of questions remains: is UMPs still required after such an extended period, or should central banks rather look at changing monetary policy approach? What about the role of fiscal policy side-by-side with monetary policy? Can the government also not look at structural challenges to the economy, thereby supporting monetary policy to deal with the problems that necessitated UMPs in the first place? UMPs boost the economy in the short run but hurt the economy in the long run.

\section{Methodology}

Data: We make use of daily data for selected QE dates, spanning from $25 / 11 / 2008-12 / 12 / 2012$. The period is restricted to 2008 - 2012 given the limitations of the econometric technique used (i.e. event study). To put this in context, the event study analysis is more robust over short horizons than long horizons. Also, previous studies (e.g. Kapetanios et al., 2012; Tatiana, 2013; Reich, 2014) have shown that the effects of QE are usually felt in the short run than in the long run. Further to this, advanced market economies have been reluctant to initiate QE programs in the later years amid global economic recovery and the dire economic effects brought about by extended QE programs. The data was collected from secondary servers including St. Louis Federal Reserve Database and Investing.com.

Model Specification: The study utilised the event study methodology which is used to investigate the effects of an event on a specific variable(s). Furthermore, a short horizon approach of the event study was exploited instead of a long horizon approach given the limitations of long horizons (Holler, 2014) Khothari and Warner (2007) state that event studies focusing on announcement effects for short horizons provide relevant and reliable evidence for understanding corporate decisions. To conduct an event study, one needs to identify the event of interest, which is UMP in our case and derive a measure of abnormal returns (Benninga, 2008; Chacha, 2017). The UMP adopted in this study is QE, which refers to actions by central banks aimed at purchasing securities from the market in order to lower interest rates and increase the money supply. Below, we present a measure of abnormal return:

$A B R_{t}=A R_{t}-E R_{t}$

Where $A B R_{t}$ is the abnormal return, $A R_{t}$ is the actual return and $E R_{t}$ is the expected return. Let $t=0$ represent the event window. Notably, we consider 10-days changes given by $(5-t)$ which is the estimation window and $(t+5)$ which is the post event window. 


\section{Figure 2: Event Time Frames}

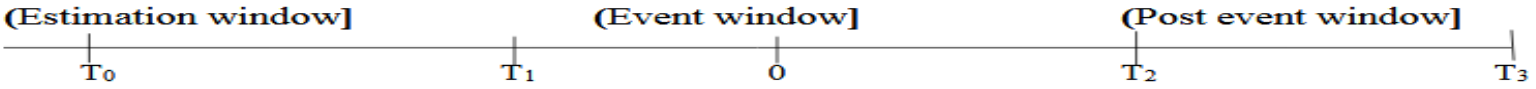

Source: Benninga (2008)

For simplicity sake, the expected return is calculated as the average of the actual return. The abnormal return is thus calculated as the difference between the normal return and the expected return. To evaluate and conclude on the impact of the events on the selected variable(s), the abnormal returns are aggregated as Cumulative Abnormal Returns (CARs). Following Khothari and Warner (2007), the CARs during the event window are calculated as:

$C A R_{t}=\sum_{t=0} A B R_{t}$

CAR is defined as the measure of the total abnormal returns during the event window and it is computed as the sum of abnormal returns during the event window.

\section{Results and Discussion}

This section details findings and their interpretation. The analysis includes tests for two countries: The United States (US), which is the country where the event took place and South Africa (SA), which is the African-country that acquired the most spill-over effects given its strong interlink age with the global financial market.

United States: Tables 1 presents data for 10-days changes in treasury bills for the first five QE1 dates. The selected dates for QE1 range from 25 November 2008 (10-day change from 20 November to 30 November) to 18 March 2009 (10-day change from 13 March to 23 March).

Table 1: 10-Day Changes in Treasury Bills (Basis Points) During QE1 Dates

\begin{tabular}{lllllll}
\hline & & \multicolumn{2}{l}{ Treasury Constant Maturity Yields } \\
Date & Event & 1-year & 3-year & 5-year & 10-year & 30-year \\
\hline 25 Nov 2008 & Initial announcement & -12 & -24 & -38 & -42 & -38 \\
$\mathbf{0 1}$ Dec 2008 & Bernanke speech & -46 & -150 & -32 & -26 & -38 \\
16 Dec 2008 & FOMC statement & -10 & -60 & 1 & -40 & -42 \\
28 Jan 2009 & FOMC statement & 6 & 24 & 27 & 26 & 25 \\
18 Mar 2009 & FOMC statement & -18 & -3 & -6 & -13 & -2 \\
Total & & $\mathbf{- 8 0}$ & $\mathbf{- 2 1 3}$ & $\mathbf{- 4 8}$ & $\mathbf{- 9 5}$ & $\mathbf{- 9 5}$ \\
\hline
\end{tabular}

Source: Authors' computations

It is worth noting that QE operates in different channels, hence its effects on different variables differ. From table 1 , we can see that 5 -year treasury yields fall by 48 basis points (bps) while 3-year treasury yields fall by $243 \mathrm{bps}$, the largest in table 1 . Additionally, 10-year yields and 30-year yields are equally significant, both falling by 95 bps. In overall, treasury yields fall by 106 bps. However, the results in Table 1 provide little evidence as to whether long term yields were more sensitive to $\mathrm{QE}$ announcements than short term yields or not. Krishnamurthy and Vissing-Jorgensen (2011), through the duration risk hypothesis, found that the yields of many long-term bonds fell more than those of short-terms bonds. Moreover, QE1 dates are significantly negative than any other dates. These findings are almost in line with existing literature although they used 2days changes (Krishnamurthy and Vissing-Jorgensen, 2011; Gagnon et al., 2011). The sum for 10-year treasury yields is -95 bps while that for Gagnon et al. (2011) was -100 bps. Table 2 presents data for the first three QE2 dates. QE2 dates range from 27 August 2010 (10-day change from 22 August to 1 September) to 3 November 2010 (10-day change from $29^{\text {th }}$ October to $8^{\text {th }}$ November). 
Table 2: 10-Day Changes in Treasury Bills (Basis Points) During QE2 Dates

\begin{tabular}{lllllll}
\hline & & \multicolumn{2}{l}{ Treasury Constant Maturity Yields } & & \\
Date & Event & 1-year & 3-year & 5-year & 10-year & 30-year \\
\hline 27 Aug 2010 & Bernanke speech & -1 & 7 & 14 & 24 & 26 \\
21 Sep 2010 & FOMC statement & 0 & -11 & -22 & -30 & -29 \\
03 Nov 2010 & FOMC statement & 2 & 18 & 15 & 6 & 29 \\
Total & & $\mathbf{1}$ & $\mathbf{1 4}$ & $\mathbf{7}$ & $\mathbf{0}$ & $\mathbf{2 6}$ \\
\hline
\end{tabular}

Source: Authors' Computations

Unlike QE1, treasury yields rose during QE2. For example, 1-year yields rose by 1 bps, 3-year yields by 14 bps, 5 -year yields by 7 bps and 30-year yields by 26 bps. QE2 seems to have had no impact on 10-year yields. In overall, treasury yields rose by 14 bps in QE2 while they fell by -243 bps during QE1, a 229 -bps difference. This finding is consistent with a similar study conducted by Financial Times (2013) which revealed QE to be having dilutive effects on asset prices overtime. For QE3, the dates range from 22 August 2012 (10-day change from 17 August to 27 August) to 12 December 2012 (10-day change from 7 December to 17 December). The results are presented in table 3.

Table 3: 10day Changes in Treasury Bills (Basis Points) During QE3 Dates

\begin{tabular}{lllllll}
\hline & & \multicolumn{2}{l}{ Treasury } & Constant Maturity Yields & & \\
Date & Event & 1-year & 3-year & 5-year & 10-year & 30-year \\
\hline 22 Aug 2012 & FOMC statement & -2 & -6 & -13 & -16 & -18 \\
13 Sep 2012 & FOMC statement & 0 & 4 & 4 & 8 & 8 \\
12 Dec 2012 & FOMC statement & -2 & 6 & 30 & 17 & 18 \\
Total & & $\mathbf{- 4}$ & $\mathbf{4}$ & $\mathbf{2 1}$ & $\mathbf{9}$ & $\mathbf{8}$ \\
\hline
\end{tabular}

Source: Authors' Computations

As can be seen in table 3, the results for QE3 dates are quite like QE2 dates, except for the 1-year treasury yield. In total, the 3-year treasury yields rose by 4 bps, 5 -year yields by 21 bps, 10 -year yields by 9 bps, 30year yields by 8 bps while 1-year treasury yields fell by 4 bps. On average, treasury yields rose by 8 bps, 6 units less than in QE2. A study by Chodorow-Reich (2014) revealed that the stock price index for life insurers in the US changed by 1.96 percentage points in QE1; 1.29 percentage points in QE2 and 1.19 percentage points in QE3, reflecting diminishing returns. These findings are in line with our study as we find QE3 to have dilutive effects relative to QE2 and QE1. The quantity of long-term securities purchased plays a crucial role on the effects of QE, which could be one of the reasons for the differences in QE effects on treasury yields.

South Africa: The findings for SA are presented in tables 4 to 6. The QE dates and events are the same as those for US. Thus, this sub-section provides findings of the spill-over effects of the US QE on the South African economy through government bonds. The bonds are chosen based on the availability of data. The bonds' durations are: 3-month, 2-year, 5-year, 10-year and 30-year. Table 4 below provides 10-days changes in government bonds during QE1 dates. It is worth noting that the data for 17th December 2008 was used instead of $16^{\text {th }}$ December 2008 since $16^{\text {th }}$ December is a public holiday in SA, hence markets close.

Table 4: 10-Day Changes in Bond - Yields (Basis Points) During QE1 Dates

\begin{tabular}{lllllll}
\hline & & \multicolumn{2}{l}{ Government Bond - Yields } & & \\
Date & Event & 3-Month & 2-year & 5-year & 10-year & 30-year \\
\hline 25 Nov 2008 & Initial announcement & -36 & -19 & -4 & 2 & 10 \\
01 Dec 2008 & Bernanke speech & 10 & -29 & -11 & -11 & -16 \\
16 Dec 2008 & FOMC statement & 5 & -32 & -28 & -27 & -20 \\
28 Jan 2009 & FOMC statement & -25 & -1 & -7 & -4 & -15 \\
18 Mar 2009 & FOMC statement & -148 & 5 & 26 & 28 & 41 \\
Total & & $-\mathbf{1 9 4}$ & $-\mathbf{- 7 6}$ & $\mathbf{- 2 4}$ & $\mathbf{- 1 2}$ & $\mathbf{0}$ \\
\hline
\end{tabular}

Source: Authors' Computations 
It is evident in table 4 that the last announcement of QE1 had the greatest impact on the 3-month government bond, falling by $148 \mathrm{bps}$. In total, the 3-month government bond fell by $194 \mathrm{bps}$, 2-year government bond by 76 bps, 5-year government bond by 24 bps, 10-year government bond by 12 bps while the 30-year government bond had nil. Table 4 further illustrates that for most dates, government bonds fell by over 10 bps. Nonetheless, Table 5 illustrates government bond yields during QE2 dates.

Table 5: 10-Day Changes in Bond - Yields (Basis Points) During QE2 Dates

\begin{tabular}{|c|c|c|c|c|c|c|}
\hline \multirow[b]{2}{*}{ Date } & \multirow[b]{2}{*}{ Event } & \multicolumn{5}{|c|}{ Government Bond - Yields } \\
\hline & & 3-Month & 2-year & 5-year & 10-year & 30-year \\
\hline 27 Aug 2010 & Bernanke speech & -30 & - & 11 & 9 & 10 \\
\hline 21 Sep 2010 & FOMC statement & -7 & - & -18 & -19 & -20 \\
\hline 03 Nov 2010 & FOMC statement & -7 & - & 11 & 10 & 16 \\
\hline Total & & -44 & - & 4 & $\mathbf{0}$ & 6 \\
\hline
\end{tabular}

Source: Authors' Computations

It is undoubtedly clear from table 5 that QE2 had a much less impact on the South African bond market. In total, the 3-month government bond fell by 7 bps which is less compared to 194 bps during QE1. Contrast to QE1, the 5-year, 10-year and 30-year government bonds rose by 11 bps, 10 bps and 16 bps, respectively, during QE2. This brings in the notion that QE has a negative impact on the financial market when used for a prolonged period. Nonetheless, table 6 provides findings from QE3 which began in 2012.

Table 6: 10day Changes in Bond - Yields (Basis Points) During QE3 Dates

\begin{tabular}{lllllll}
\hline & & \multicolumn{2}{l}{ Government Bond - Yields } & & \\
Date & Event & 3-Month & 2-year & 5-year & 10-year & 30-year \\
\hline 22 Aug 2012 & FOMC statement & 0 & - & -8 & -8 & -1 \\
13 Sep 2012 & FOMC statement & 0 & - & 2 & 10 & 30 \\
12 Dec 2012 & FOMC statement & 1 & - & -14 & -11 & -9 \\
Total & & $\mathbf{1}$ & - & $\mathbf{- 2 0}$ & $\mathbf{- 9}$ & $\mathbf{2 0}$ \\
\hline
\end{tabular}

Source: Authors' Computations

Table 6 indicates that QE3 had a mixture of diluted and muted effects on government bond yields. The first and second announcements had muted effects on the 3-month government bond. The third announcement had a positive impact on 5-year, 10-year and 30-year government bonds as bond yields fell by $14 \mathrm{bps}, 11 \mathrm{bps}$ and 9 bps, respectively. However, the overall impact on the 30-year government bond was negative as yields fell by 20 bps. Given the values in tables 4 to 6, it can be concluded that QE1 had the greatest impact on the bond market than QE2 and QE3. These findings are consistent with the Financial Times (2013) study which revealed that QE2 and QE3 had diluted and muted effects whereas QE1 had a significant impact on most asset prices.

\section{Conclusion and Recommendations}

The study aimed to assess the impact and spill over effects of Unconventional Monetary Policies (UMPs); identify the potential risks associated with UMPs. Having identified that UMPs are associated with the risk of increasing inflation and low profitability of financial institutions, the event analysis methodology was used to achieve the stated objectives. The sample included the United States (US) as the country where the event occurred and South Africa (SA) as a country that acquired the most spill-over effects after the global financial crises of 2007-2008. It was therefore found that US Treasury bills fall by 106 basis points on average during QE1, rise by 9 basis points and 8 basis points during QE2 and QE3, respectively. As for South Africa, government bonds fall by 61 basis points on average during QE1, 9 basis points during QE2 and 2 basis points during QE3. Therefore, it is noted that when considering US treasury bills and SA government bonds, UMPs bodes well for significant stabilisation of the economy in the short run. As the purchase of the afore- 
mentioned securities (treasury bills and government bonds) are associated with high risk, its use to correct disastrous global events like the global financial crises can be achieved in the short horizon but could hurt the economy in the long run. Nonetheless, this study also displayed to some extent, diverse perspectives by different academics and researchers, whereby some ideas complement each other. As stated by Botezatu and Diaconescu (2014), the use of unconventional measures (QE in this case) appears to be appropriate in certain circumstances.

However, the timing of using these measures is equally important as they bring about consequences. It has not yet proven that the marginal costs of using UMPs exceed the marginal benefits of using those policies (Botezatu and Diaconescu, 2014). However, UMPs became a problem rather than a solution when they were used for an extended period. The financial crisis necessitated the need to consider financial stability as prerequisite for the proper functioning of transmission mechanisms. Similarly, macroeconomic stability requires financial stability (Ortiz, 2010). It is recommended that the decision to halt the use of UMPs requires careful judgment on the appropriate sequencing and speed of monetary action. Therefore, policymakers must allow for possibility that interaction of unconventional and conventional policy elements may alter normal transmission mechanism. The cooperation of international monetary policy together with policy rules that are sound should be enforced to revert within stable international monetary system. It is also required that, given previous financial crisis, better understanding of appropriate policy response is important. It is necessary to understand the source of financial stability and understand how cross-border cooperation can assist to provide public good of international financial rules and systems. The policymakers should concentrate much on the overall financial system to measure the risk, and thus consistently strengthen macro prudential orientation.

\section{References}

Bank of England pamphlet. (2011). Quantitative easing explained.

Benninga, S. (2008). Financial Modelling (Third ed.). Boston: MA:MIT Press.

Bernanke, B. S. (2009). Federal Reserve Policies to Ease Credit and their Implications for the FEd's Balance Sheet. Washington D.C: The National Press Club Luncheon.

Bhattarai, S., Eggertsson, G. B. \& Gafarov, B. (2015). Time Consistency and the Duration of Government Debt: A Signalling Theory of Quantitative Easing. 1050 Massachusetts Avenue, Cambridge, MA 02138: National Bureau of Economic Research.

Bhattarai, S., Chatterjee, A. \& Woong, Y. (2015). Effects of US Quantitative Easing on Emerging Market Economies. UNSW Business School Research Paper NO. 2015-26. Retrieved from SSRN: https//ssrn.com/abstract $=2685500$

Borio, C. (2011). Central Banking post - Crisis: What compass for unfigured water? Monetary and Economic Department, 353.

Borio, C. \& Zabai, A. (2016). Unconventional Monetary Policies: A re-appraisal. BIS Working Paper, 570.

Borio, C. E. V. \& Shim, I. (2007). What can macro-prudential policy do to support monetray policy? Monetary and Economic Department. BIS working paper, 242.

Botezatu, H. P. \& Diaconescu, D. R. (2014). Financial Stability Due to the Unconventional Monetary Policies. Internationa Journal of Business and Management, 2, 11-24.

Bowdler, C. \& Radia, A. (2012). Unconventional monetary policy: the assessment. Oxford Review of Economic Policy, 28(4), 603-621.

Cecioni, M., Ferrero, G. \& Secchi, A. (2011). Unconventional Monetary Policy in Theory and in Practice. Questioni di Economia e Finanza Occational papers, 102.

Chacha, T. (2017). The effect of Fed's Quantitative Easing Policy on Listed Companies and Sectors in South Africa. South Africa: University of Cape Town.

Chodorow-Reich, G. (2014). Effects of Unconventional Monetary Policy on Financial Institutions. Brooking papers on economic activity. Harvard University.

Chodorow-Reich, G. (2014). The Effect of Unconventional Monetary on Financial Institutions. Brookings panel on Economic activity Spring. Washington D.C: Brookings.edu.

Francios, D. \& Mathieu, D. A. (2016). Post-crisis monetary policies: Economic Viewpoint. Retrieved from Desjardins Economic Studies: www.desjardins.com/economics 
Gagnon, J., Raskin, M., Remache, J. \& Sack, B. (2011). Large-Scale Asset Purchases by the Federaal Reserve:Did They Work? FRBNY Economic Policy Review, 17, 41-59.

Holler, J. (2014). Event-study methodology and statistical significance. Germany: O1WIR Publisher for Economics, Computer Science and Law.

Horvath, R. (2017). Side effects of Unconventional Monetary Policy: Policy Department-Economic and Scientific policy. Directorate General for Internal Policies. Retrieved from Investing.com: https://za.investing.com/rates-bonds/south-africa

Joyce, M., Miles, D., Scott, A. \& Vayanos, D. (2012). Quantitative Easing and Unconventional Monetary Policy An Introduction. The Economic Journal, 122(564), 271-288.

Kapetanios, G., Mumtaz, H. S. \& Theodoridis. (2012). Assessing the economy - wide effects of quantitative easing. Bank of England Working paper, 443.

Kenc, T., Turhan, M. I. \& Yildirim, O. (2011). The Experience with Macro-Prudential Policies of the Central Bank of the Republic of Turkey in Response to the Global Financial Crisis. Policy Research Working paper, 5834.

Khothari, S. P. \& Warner, J. B. (2007). Handbook of Corporate Finance: Empirical Corporate Finance, Vol. 1. North Holland: Elsevier.

Korniyenko, Y. \& Loukoianova, E. (2015). The Impact of Unconventional Monetary Policy Measures by the Systematic Four on Global Liquidity and Monetary Conditions. IMF WOrking PAper, 287.

Krishnamurthy, A. \& Vissing-Jogensen, A. (2011). The Effects of Quantitative Easing on Interest Rates.

Lenza, M., Pill, H. \& Reichlin, L. (2010). Monetary policy in Exceptional Times. Journal of Economic Policy, 25, 295-339.

Liber8 Newsletter. (2011). Quantitative Easing Explained: An informative and accessible economic essay with a classroom application. Retrieved from Stlouisfed: www.stlouisfed.org/education.

Meier, A. (2009). Panacea, curse, or non-event: Unconventional Monetary Policy in the United Kingdom. IMF Working Paper, 09/163.

Oosthuizen, H. (2016). Policy Implications for South Africa as a result of Quantitative Easing and Monetary Policy Normalisation.

Ortiz, G. (2010). The Future of Central Banking under Post - Crisis Mandates. Ninth BIS Annual Conference.

Punzi, M. T. \& Chantapacdepong, P. (2017). Spillover Effects of Unconventiona Monetary Policy in Asia and the Paicific. Tokyo, Japan: Asian Development Bank Institute.

Reich, C. (2014). Effects of Unconventional Monetary Policy on Financial Institutions. Harvard University.

Rossi, B. (2018). Identifying and estimating the Effects of Unconventional Monetary Policy in the Data: How to Do It and What have we Learned? Barcelona GSE, and CREI: ICREA-Univ.Pompeu Fabra.

Stephanos, P., Nikolaos, A. K. \& Panayiotis, G. T. (2019). Spillover Effects of US QE and QE Tapering on African and MIddle Eastern Stock Indices. Journal of Risk and Financial Management, 12(57), 1-20.

Subacchi, P. (2013). Coordinating the Next Move, Monetary Policy in the Post-crisis World: Think Tank 20: The G-20 and Central Banks in the New World of UMP.

Tatiana, F. (2013). The spillover effects of Unconventional Monetary Policies in major developed countries on developing countries. Department of Economic and Social Affairs, Working Paper, 131.

Velde, D. (2008). The Global Financial Crisis and Developing Countries: Which countries are at risk and what can be done? Overseas Development Institute.

Vinals, J., Blanchard, O. \& Tiwari, S. (2013). Global Impact and Challenges of Unconventional Monetary Policies. IMF Policy Paper.

Weale, M. \& Wieladek, T. (2014). What are the macroeconomic effetcs of asset purchases? External MPC Unit Discussion Paper, 42.

Yasin, A., Ahmet, F. \& Arif, O. (2013). Central Banking in making during the Post-Crisis world and the Policymix of the Central bank of the Republic of Turkey. Journal of Central Banking Theory and Practice, 2, $5-18$. 